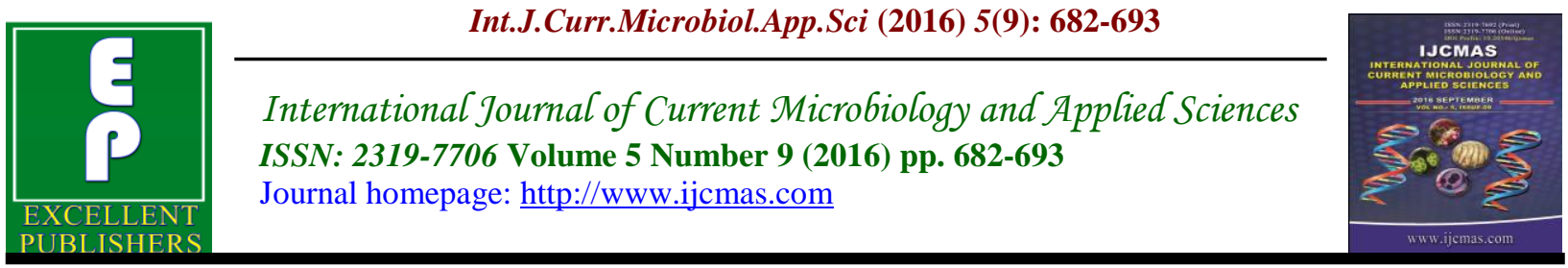

Original Research Article

http://dx.doi.org/10.20546/ijcmas.2016.509.079

\title{
Prevalence of Fungal Phytopathogens on Transgenic Bt Cotton Plant: Isolation and Characterization
}

\author{
Leena P. Shirsath and Ulhas K. Patil* \\ Department of Microbiology and Biotechnology, R. C. Patel Arts, Commerce and Science \\ College, Shirpur - 425405, India \\ *Corresponding author
}

A B S T R A C T

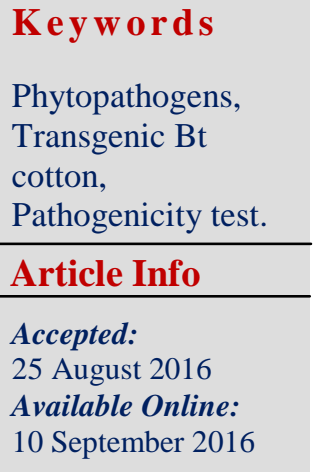

Keywords

Phytopathogens, Transgenic Bt cotton, Pathogenicity test.

Article Info

Accepted:

10 September 2016
The prevalence of leaf spots and wilt of transgenic Bt cotton were surveyed in several cotton fields of North Maharashtra region, India. In this study, total four phytopathogenic fungal strains from the affected cotton plants were isolated and characterized. The pathogenicity of fungal strains was confirmed by Koch's postulates. The pathogenicity tests showed that all the isolated fungal strains are phytopathogen of the Bt cotton plant. Among the four fungal isolates, the prevalence of Fusarium chlamydosporum as potential phytopathogen of cotton is documented for the first time from India.

\section{Introduction}

Cotton is one of the most noteworthy and widely cultivated fiber crops. More than 50 countries located at tropical and subtropical regions of the world produces economically important cotton crop. Among them, India has largest area under cotton cultivation constituting about $30 \%$ of the global cotton area (WWF-India, 2012). Cotton plays an important role in sustaining the Indian economy as India is the world's second largest cotton producer (Khadi et al., 2009). Among the major cotton growing regions of India, North Maharashtra region alone occupies 5 lakh ha $(5.23 \%$ of total land of India) area under cotton cultivation (Patil and Waykole, 2013) and is known to have high potential for cotton yield (Gopalakrishnan et al., 2007).

This important agricultural commodity is sensitive to a number of biotic and abiotic stresses and the diseases. Due to wide distribution and long exposure (5-6 months for planting to harvest) to the changing climatic condition, number of diseases are prevalent on cotton crop which affects the final yield (Bell, 1999). According to Agrios (2005), the estimated $36.5 \%$ average of total losses includes - $14.1 \%$ caused by diseases (fungi, bacteria and viruses), $10.2 \%$ by insects and $12.2 \%$ by weeds. Largest crop loss $(14.1 \%)$ is by phytopathogens alone. 
Among the phytopathogens, over 30 species of fungi can cause cotton plant infections (Farrell and Johnson, 2005). The present investigation emphasizes - isolation and identification of the phytopathogenic fungi associated with the transgenic Bt cotton plant cultivated in North Maharashtra region of India.

\section{Materials and methods}

\section{Field survey and sampling}

A rigorous and periodical field surveys were carried out in severely affected cotton fields cultivated with Bt-cotton variety ( $\mathrm{RCH}-2)$ from North Maharashtra region (Dhule, Jalgaon and Nandurbar Districts) in the year 2012- 2014. During this survey, the cotton leaves, stem and developing cotton bolls were noticed with leaf spots. Another noticeable symptom was wilting of cotton plant. The majority of cotton plants showed reduced growth and less vigor and vitality.

Another survey was conducted to compare whether the cotton seed sown in May or June has contributed in inducing the wilt and foliar disease. Total 15 different cotton fields located in North Maharashtra region were examined for appearance of disease symptoms. The five random micro plots of $25 \times 25 \mathrm{~m}^{2}$ area with at least 50 plants/microplot were examined for diseased plants. The diseased plant parts (leaves, root, stem and developing cotton bolls) were collected in airtight polyethylene bags as specimen for fungal isolation. These specimens were stored at $4^{\circ} \mathrm{C}$ until further use.

\section{Isolation and identification of the fungal strains}

The collected plant specimens - root, stem, leaves, and bolls were washed under running tap water and then blotted dry using sterile filter paper. These specimens were further surface sterilized with $0.5 \%$ sodium hypochlorite (for $1 \mathrm{~min}$ ) followed by washing with sterile distilled water (Zheng et al., 2011). The appropriate blocks $(5 \times 5$ $\mathrm{mm}$ ) of infected tissue of root, stem, leaves and bolls were cut and placed on a modified Czapek dox agar (CDA) plates having the composition (g/L): Sucrose, 30; $\mathrm{NaNO}_{3}, 0.5$; $\mathrm{K}_{2} \mathrm{HPO}_{4}, \quad 0.5 ; \quad \mathrm{MgSO}_{4}, \quad 0.5 ; \mathrm{KCl}, \quad 0.50$; $\mathrm{FeSO}_{4}, 0.01$; Streptomycin, 0.05; Agar, 20; $\mathrm{pH}$ 7.2. The plates were incubated at $28 \pm$ $2^{\circ} \mathrm{C}$ for 7 days. The isolated strains were sub-cultured several times to ensure the purity and maintained on CDA medium at $4^{\circ} \mathrm{C}$.

The morphological characteristics of all the isolated fungal strains were studied by slide culture assembly. The morphological features (colony characteristics, mycelial growth pattern, radial growth pattern, spore forms, size of the conidia) were scientifically examined as per key described by Alexopoulos et al., 1996; WilliamsWoodward, 2001; Dugan, 2006. The identification of isolated fungal strains was further verified at National Fungal Culture Collection of India, Agharkar Research Institute (NFCCI-ARI), Pune (India).

\section{Pathogenicity test}

The isolates were corroborated for their ability to induce infection/disease on cotton plant. The pathogenicity test was conducted on cotton plant as well as cotton seed. The re-isolation of inoculated fungi from symptomatic plants was conducted to confirm the pathogenicity of isolates by Koch's postulates.

\section{Pathogenicity test on cotton plant}

Three week old (four-leaf stage of plant) healthy $\mathrm{Bt}$ cotton ( $\mathrm{RCH}-2)$ plants; grown in $13 \times 11 \mathrm{~cm}$ plastic pots containing an 
autoclaved soil were selected for the experiment. During the experiment, five pots each containing two plants were infected by respective fungal isolate. Similarly, five pots (each with two plants) were kept as control. Experiments were carried out in quadruplets. The spore suspension prepared in sterile distilled water amended with $0.1 \%$ Tween 80 (total spore count $-10^{6}$ spores $/ \mathrm{ml}$ ) was employed in the infectivity assay. The control plants were treated with sterile distilled water containing Tween $80(0.1 \%)$. The plants were grown in at $30 / 25{ }^{\circ} \mathrm{C}$ (day/night temperature) with a $16 \mathrm{~h}$ of photo period in green house and watered on alternate days. The disease progression in each plant was assessed by observing signs and symptoms in plant up to 45 days. The disease symptoms of each plant were rated by analyzing the root browning, vascular discoloration and vigor.

The 0-4 scale was used for analysis of stem and root infection consists: $0=$ no symptoms, $1=<10 \%$ root browning with the over ground part having no symptoms, $2=11-50 \%$ root browning \& plant with less than $50 \%$ of its crown with wilt; $3=>50 \%$ root browning \& plant with greater than $50 \%$ of its crown with wilt, and $4=$ browning of most of the root, plant dead (Zhao et al., 2014).

The plants showing leaf infection were rated by detecting (i) round or irregular shaped spots (2 to $5 \mathrm{~mm}$ ), (ii) dark brown to grey in coloration and (iii) bright yellow margin on dry leaf. The 0-4 scale was used for analysis of leaf infection: $0=$ no symptoms, $1=<10 \%$ leaf spot, $2=11-50 \%$ leaf spot; $3=>50 \%$ leaf spot and $4=$ leaf spot all over the leaf (Shtienberg, 1996). The disease severity index (DSI) ranged from 0 (no disease) to 100 (plants death or complete diseased plant) and calculated as per Zhao et al., 2014.
DSI

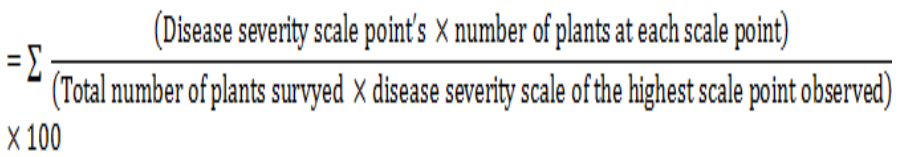

Analysis of variance (ANOVA) was conducted on the DSI data to determine the overall effect of the isolates and their interactions with cotton plant. The comparisons of the mean DSI data were made using Dunnets multiple range test $(P<0.05)$.

\section{Pathogenicity test on seed}

The pathogenicity of fungal isolate on cotton seed (Bt RCH- 2) germination was evaluated by calculating percent seed germination and by observing the plants vigor index. The virulence of fungal isolate to attack on seed germination was analyzed by (i) seed treatment method and (ii) soil treatment method. For both the experiments all the cotton seeds were surface sterilized using $1 \%(\mathrm{v} / \mathrm{v})$ sodium hypochlorite followed by rinsing with sterile distilled water for three times.

For evaluation of seed infectivity by seed treatment method, forty seeds were soaked in $20 \mathrm{ml}$ of spore suspension $\left(10^{6}\right.$ spores $\left./ \mathrm{ml}\right)$ of respective fungal isolate for 8 hours while controls were treated with sterile distilled water. The treated seeds were then incubated onto sterile moist filter paper containing plate $\left(10\right.$ seeds/plate) at $28^{\circ} \mathrm{C}$. On next day, the seeds were transferred to pot containing autoclaved soil (4 seeds/pot) (Shin et al., 2014). Similarly, for the evaluation of seed infectivity by soil treatment method, the seeds were sown (4 seeds/ pot) in 10 pots containing autoclaved soil thoroughly mixed with respective fungal isolates having spore density $10^{6}$ spores $/ \mathrm{ml}$. The control sets were treated with distilled water (Islam and Borthakur, 2012). 
The inoculated pots were grown in a greenhouse at $30 / 25^{\circ} \mathrm{C}$ day/night temperature with a $16 \mathrm{~h}$ of photo period and watered on alternate days. The number of seeds germinated was recorded as seedling with coleoptiles length $>1 \mathrm{~cm}$ at 7 days of incubation. Germination percentages were recorded as, the number of germinating seeds inoculated with respective fungal isolate divided by the number of germinated control seeds.

\section{Plant vigor index}

The vigor index of all the experimental cotton plants (emerge by seed and soil treatment method) were determined at the end of experiment (45 days) as per Lee et al. (2008). The vigor index was calculated by formula-

Vigor index $=($ Mean of root length + Mean of shoot length) $\times$ Percentage of seed germination.

\section{Results and Discussion}

\section{Isolation and identification of the fungal pathogens}

Based on field survey of major cotton growing regions of North Maharashtra it was observed that the incidence of fungal infection was highly prevalent on cotton plant. Several irrigated cotton fields cultivated with Bt (cotton-Rasi 2 variety) were witnessed as severely infected which is characterized by slow growth, less vigor and vitality, wilting and foliar infection during the month June to September in the year 2012- 2014.

Another survey was conducted to compare the variation of wilt and foliar disease symptoms according to seed sowing time (May-June). The results of survey showed that there was variation in disease symptoms according to seed sowing time.The average minimum/ maximum temperature and humidity of the month May was recorded as $27.13 / 40.87^{\circ} \mathrm{C}$ and $30.27 / 71.2$ respectively. While the average minimum/ maximum temperature and humidity of the month June was recorded as $26.57 / 38.27^{\circ} \mathrm{C}$ and $32.8 / 75.93$ respectively. The data presented in Table1 showed that the disease incidences of wilting symptoms are higher $(28.27 \%)$ in cotton plants which were sowed in the month of May as compare to the cotton plants which were sowed in June (23.47) (after rain). Similarly the disease incidences $(28.13 \%)$ for foliar disease symptoms were highly associated with plants that were sowed in June rather than sowed in May.

Total four fungal strains L1, L2, L4 and L8 were isolated during the study. Table 2 represents the identification of fungal strains studied in this investigation. The fungal strains L1, L2, L4 and L8 were identified and deposited at National Fungal Culture Collection of India, Agharkar Research Institute (NFCCI-ARI), Pune (India).

All the fungal isolates were grown on Czapek dox agar plates at $28 \pm 2{ }^{\circ} \mathrm{C}$ and were studied for their cultural and morphological characteristics. Table 3 summarizes the morphological feature and cultural characteristics. Fig.1 shows morphological observation of fungal isolates.

\section{Pathogenicity of fungal isolates}

\section{Pathogenicity on cotton plant}

The result of the pathogenicity test of all the four isolated fungi showed significant visible disease symptoms on cotton plant (Fig.2). Among the foliar disease causing fungi Corynespora cassicola (NFCCI 2952) showed maximum DSI as compare with Alternaria sp. (NFCCI 2955). Corynespora 
cassicola and Alternaria sp. showed statistically significant DSI value when compared with control. While both the Fusarium species showed significant DSI value as compare with control cotton plant. Fusarium chlamydosporum (NFCCI 2948) showed slightly higher DSI than Fusarium moniliforme (NFCCI 2949) (Table 4).

Pathogenicity was also determined by measuring the vigor index of test and control plant. All the tested fungal isolates showed reduction in vigor index (Table 4). Fusarium moniliforme was the most virulent isolate showing $68.56 \%$ reduction in vigor index over control.

\section{Seed germination}

Fungal isolates were also studied for their effect on seed germination. All the studied fungal strains showed a considerable reduction of seed germination (Fig.3). In overall seed germination assay soil treatment method showed more reduction in seed germination as compare with seed treatment method. Among all the four fungal isolates Fusarium chlamydosporum and Fusarium moniliforme showed maximum reduction in cotton seed germination.

Similarly, Corynespora cassicola and Alternaria sp. also showed a profound (near about $50 \%$ reduction in seed germination) effect on reduction in seed germination (Fig.4). Plants emerged from remaining germinated seeds of these experiment were studied for vigor index. All the four isolates contributed in reduction of plants root and shoot length.

Table.1 Wilt and foliar Disease incidences on cotton

\begin{tabular}{|c|c|c|c|c|c|c|c|c|}
\hline \multirow[b]{2}{*}{$\begin{array}{c}\text { Field } \\
\text { No. }\end{array}$} & \multicolumn{4}{|c|}{ Seed sowing in May } & \multicolumn{4}{|c|}{ Seed sowing in June } \\
\hline & $\begin{array}{c}\text { Temperature } \\
{ }^{\circ} \mathrm{C} \\
\text { (Min/Max) }\end{array}$ & $\begin{array}{c}\text { Humidity } \\
\text { (Min/Max) } \\
(\%)\end{array}$ & $\begin{array}{c}\text { Wilt } \\
\text { disease } \\
\text { symptoms } \\
\text { (DI) }\end{array}$ & $\begin{array}{c}\text { Foliar } \\
\text { disease } \\
\text { symptoms } \\
\text { (DI) }\end{array}$ & $\begin{array}{c}\text { Temperature } \\
{ }^{\circ} \mathrm{C} \\
\text { (Min/Max) }\end{array}$ & $\begin{array}{c}\text { Humidity } \\
\text { (Min/Max) } \\
(\%)\end{array}$ & $\begin{array}{c}\text { Wilt } \\
\text { disease } \\
\text { symptoms } \\
\text { (DI) }\end{array}$ & $\begin{array}{c}\text { Foliar } \\
\text { disease } \\
\text { symptoms } \\
\text { (DI) }\end{array}$ \\
\hline 1. & $26 / 41$ & $24 / 75$ & 24 & 14 & $26 / 40$ & $32 / 78$ & 18 & 32 \\
\hline 2. & $28 / 40$ & $17 / 70$ & 40 & 16 & $27 / 39$ & $26 / 79$ & 20 & 30 \\
\hline 3. & $26 / 42$ & $15 / 73$ & 16 & 12 & $26 / 38$ & $34 / 76$ & 26 & 34 \\
\hline 4. & $28 / 40$ & $19 / 72$ & 28 & 20 & $27 / 40$ & $31 / 72$ & 24 & 28 \\
\hline 5. & $29 / 41$ & $21 / 64$ & 36 & 24 & $28 / 37$ & $34 / 78$ & 18 & 26 \\
\hline 6. & $28 / 43$ & $18 / 78$ & 26 & 18 & $26 / 38$ & $37 / 79$ & 30 & 34 \\
\hline 7. & $27 / 41$ & $30 / 73$ & 28 & 14 & $27 / 37$ & $30 / 80$ & 12 & 20 \\
\hline 8. & $27 / 40$ & $32 / 68$ & 20 & 12 & $28 / 40$ & $32 / 76$ & 24 & 22 \\
\hline 9. & $26 / 41$ & $37 / 71$ & 20 & 16 & $26 / 38$ & $36 / 75$ & 22 & 30 \\
\hline 10. & $26 / 40$ & $53 / 81$ & 32 & 22 & $26 / 39$ & $34 / 74$ & 32 & 36 \\
\hline 11. & $25 / 39$ & $30 / 72$ & 30 & 18 & $25 / 38$ & $32 / 71$ & 34 & 30 \\
\hline 12. & $29 / 42$ & $19 / 69$ & 26 & 16 & $27 / 39$ & $31 / 69$ & 26 & 30 \\
\hline 13. & $26 / 39$ & $35 / 74$ & 26 & 12 & $28 / 38$ & $30 / 75$ & 18 & 22 \\
\hline 14. & $26 / 42$ & $53 / 65$ & 38 & 30 & $25 / 37$ & $37 / 78$ & 34 & 28 \\
\hline 15. & $30 / 42$ & $51 / 63$ & 34 & 26 & $26 / 36$ & $36 / 79$ & 14 & 20 \\
\hline Mean & $27.13 / 40.87$ & $71.2 / 30.27$ & 28.27 & 18 & $26.57 / 38.27$ & $32.8 / 75.93$ & 23.47 & 28.13 \\
\hline
\end{tabular}


Table.2 Isolation and identification of pathogenic fungal strain from different parts of cotton plant

\begin{tabular}{lllll}
\hline $\begin{array}{l}\text { Sr. } \\
\text { No. }\end{array}$ & Isolate & \multicolumn{1}{c}{ Name } & Accession no. & Isolated from \\
\hline 1. & L1 & $\begin{array}{l}\text { Fusarium fusarioides } \\
\text { (syn.= chlamydosporum) }\end{array}$ & NFCCI 2948 & Stem \\
2. & L2 & Fusarium moniliforme & NFCCI 2949 & Root \\
3. & L4 & Corynespora cassicola & NFCCI 2952 & Leaves \\
4. & L8 & Alternaria sp. & NFCCI 2955 & Leaves \\
\hline
\end{tabular}

Table.3 Visual characteristics of fungal isolates on Czapek dox agar medium after 7 days incubation

\begin{tabular}{|c|c|c|c|c|}
\hline Characteristics & $\begin{array}{l}\text { Fusarium } \\
\text { chlamydosporum }\end{array}$ & $\begin{array}{l}\text { Fusarium } \\
\text { moniliforme }\end{array}$ & $\begin{array}{l}\text { Corynespora } \\
\text { cassicola }\end{array}$ & $\begin{array}{l}\text { Alternaria } \\
\text { sp. }\end{array}$ \\
\hline $\begin{array}{l}\text { Growth rate } \\
(\mathrm{mm} / \mathrm{d})^{\mathrm{a}}\end{array}$ & $11.67 \pm 5.16$ & $12.67 \pm 3.14$ & $9 \pm 2.28$ & $15.2 \pm 2.39$ \\
\hline $\begin{array}{l}\text { Colony diameter } \\
(\mathrm{mm}) \\
\text { Mean } \pm \mathrm{SD}\end{array}$ & $79.67 \pm 1.53$ & $86.33 \pm 1.53$ & $56.33 \pm 0.58$ & $89.67 \pm 0.58$ \\
\hline $\begin{array}{l}\text { Mycelia growth } \\
\text { pattern }\end{array}$ & $\begin{array}{l}\text { Good growth, aerial, } \\
\text { floccose, Circular } \\
\text { growth }\end{array}$ & $\begin{array}{l}\text { Good growth, aerial, } \\
\text { floccose to powdery } \\
\text { circular growth }\end{array}$ & $\begin{array}{l}\text { Moderate growth, } \\
\text { circular, flat textured, } \\
\text { smooth margin }\end{array}$ & $\begin{array}{l}\text { Fast growth, Circular, } \\
\text { thin, flat, rough margin }\end{array}$ \\
\hline Colony colour & $\begin{array}{l}\text { Top- White } \\
\text { Bottom- Light orange }\end{array}$ & $\begin{array}{l}\text { Top- White } \\
\text { Bottom- Pale yellow, } \\
\text { tinged with purple }\end{array}$ & $\begin{array}{l}\text { Top - Grey } \\
\text { Bottom- Black }\end{array}$ & $\begin{array}{l}\text { Top- Olivaceous } \\
\text { greenish black } \\
\text { Bottom- Black }\end{array}$ \\
\hline Conidia & $\begin{array}{l}\text { Thick walled and } \\
\text { moderately curved. } \\
\text { Unequal dorsiventral } \\
\text { curvature, i.e., the upper } \\
\text { wall is curved and the } \\
\text { lower wall is almost } \\
\text { straight. Short and } \\
\text { pointed apical cell }\end{array}$ & $\begin{array}{l}\text { Hyaline, thin walled, } \\
\text { formed in chains, } \\
\text { straight to slightly sickle } \\
\text { shaped. }\end{array}$ & $\begin{array}{l}\text { Hyaline, long, straight } \\
\text { to slightly curved, } \\
\text { Obclavate to cylindrical } \\
\text { and apex obtuse }\end{array}$ & $\begin{array}{l}\text { Ovoid or ellipsoid in the } \\
\text { larger initial units, then } \\
\text { progressively broader } \\
\text { ovoid, then smaller } \\
\text { ovoid in terminal regions } \\
\text { of the chain. } \\
\text { Multicellular, are } \\
\text { produced in straight } \\
\text { chains, or branching } \\
\text { chains. The end of the } \\
\text { conidium has a beak-like } \\
\text { appearance }\end{array}$ \\
\hline Conidia size $^{b}$ & $\begin{array}{l}32.12 \mu \mathrm{m} \text { long and } \\
4.35 \mu \mathrm{m} \text { wide }\end{array}$ & $\begin{array}{l}13.44 \mu \mathrm{m} \text { long and } \\
2 \mu \mathrm{m} \text { wide }\end{array}$ & $\begin{array}{l}56.23 \mu \mathrm{m} \text { long and } \\
7.47 \mu \mathrm{m} \text { wide }\end{array}$ & $\begin{array}{l}47.16 \mu \mathrm{m} \text { long and } \\
13.49 \mu \mathrm{m} \text { wide }\end{array}$ \\
\hline Septa & septate (2-4) & septate (3-6) & $\begin{array}{l}\text { Pseudo septa } \\
(4-12)\end{array}$ & $\begin{array}{l}\text { Vertical (1-2) and } \\
\text { Transverse septa (6-7) }\end{array}$ \\
\hline Sporulation $^{c}$ & Good & Moderate & Abundant & Moderate \\
\hline
\end{tabular}

a Growth rate was taken after 7 days of incubation at $28^{\circ} \mathrm{C}$

b mean values of length and width of 50 randomly picked macro conidia \pm standard deviation.

c Sporulation was measured after 7 days of incubation at $28^{\circ} \mathrm{C}$. 
Table.4 Pathogenicity test on cotton plant. Disease severity index and vigor index when healthy plant was artificially inoculated with four fungal isolates

\begin{tabular}{lccc}
\hline Fungal isolate & $\begin{array}{c}\text { Disease severity } \\
\text { Index } \\
\text { (DSI)* }\end{array}$ & $\begin{array}{c}\text { Vigor } \\
\text { Index }\end{array}$ & $\begin{array}{c}\text { Percentdecrease of vigor } \\
\text { index over control }\end{array}$ \\
\hline Corynespora cassicola & $43.63 \mathrm{a}$ & 2219.38 & 44.96 \\
Alternaria sp. & $42 \mathrm{a}$ & 2476.29 & 38.59 \\
Control & 0.25 & 4032.34 & - \\
\hline Fusarium chlamydosporum & $40.25 \mathrm{a}$ & 1397.43 & 65.93 \\
(=fusarioides) & $39.00 \mathrm{a}$ & 1289.45 & 68.56 \\
Fusarium moniliforme & 2.50 & 4102.32 & - \\
Control & & & \\
\hline
\end{tabular}

DSI $=\sum$ (disease severity scale point's $\times$ number of plants at each scale point $) /$ (total number of seeds surveyed $\times$ disease severity scale of the highest scale point observed) $\times 100$.

Mean in each coloum followed by the same letter are not significantly different within treatment group calculated by one way ANOVA using Dunnets multiple range test $(P>0.05) . P<0.05$ Vs Control after treatment

Table.5 Pathogenicity test on cotton seed. Disease severity index and vigor index when cotton seeds were artificially inoculated (Seed inoculation and Soil inoculation method) with four fungal isolates

\begin{tabular}{|c|c|c|c|c|c|c|}
\hline \multirow[t]{2}{*}{ Fungal isolate } & \multicolumn{2}{|c|}{$\begin{array}{c}\text { Disease severity Index } \\
(\text { DSI })^{*}\end{array}$} & \multicolumn{2}{|c|}{ Vigor index } & \multicolumn{2}{|c|}{$\begin{array}{l}\text { Percent decrease of vigor } \\
\text { index over control }\end{array}$} \\
\hline & $\begin{array}{c}\text { Seed } \\
\text { inoculation }\end{array}$ & $\begin{array}{c}\text { Soil } \\
\text { inoculation }\end{array}$ & $\begin{array}{c}\text { Seed } \\
\text { Treatment }\end{array}$ & $\begin{array}{c}\text { Soil } \\
\text { Treatment }\end{array}$ & $\begin{array}{c}\text { Seed } \\
\text { Treatment }\end{array}$ & $\begin{array}{c}\text { Soil } \\
\text { Treatment }\end{array}$ \\
\hline Corynespora cassicola & $45.63 \mathrm{a}$ & $51.25 \mathrm{a}$ & 2505.28 & 2383.15 & 37.73 & 40.24 \\
\hline Alternaria sp. & $45 \mathrm{a}$ & $50.63 \mathrm{a}$ & 2111.85 & 2314.73 & 47.51 & 41.96 \\
\hline Control & 0.25 & 0.5 & 4023.64 & 3988.21 & - & - \\
\hline $\begin{array}{l}\text { Fusarium } \\
\text { chlamydosporum } \\
\text { (=fusarioides) }\end{array}$ & $41.25 \mathrm{a}$ & 46.25 & 1285.38 & 1179.6 & 67.45 & 72.11 \\
\hline Fusarium moniliforme & $39.38 \mathrm{a}$ & 40.63 & 1286.95 & 1185.93 & 67.41 & 71.96 \\
\hline Control & 2.50 & 1.88 & 3948.88 & 4229.1 & - & - \\
\hline
\end{tabular}

DSI $=\sum$ (disease severity scale point's $\times$ number of plants at each scale point)/ (total number of seeds surveyed $\times$ disease severity scale of the highest scale point observed) $\times 100$.

Mean in each coloum followed by the same letter are not significantly different within treatment group calculated by one way ANOVA using Dunnets multiple range test $(P>0.05) . P<0.05$ Vs Control after treatment 
Fig.1 Fig. 1 Growth pattern of fungal isolates after 7 days of incubation at 28 on Czapek Dox agar (a) Fusarium chlamydosporum, (b) Fusarium moniliforme, (c) Corynespora cassicola, (d) Alternaria sp.

Morphological features of fungal hyphae observed under microscope (40xobjective) (e) Fusarium chlamydosporum, (f) Fusarium moniliforme, (g) Corynespora cassicola, (h) Alternaria sp. $($ Scale bars $=25 \mu \mathrm{m})$

(a)

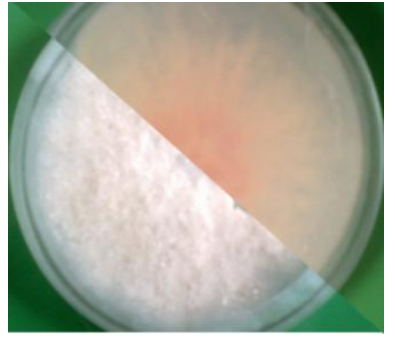

(b)

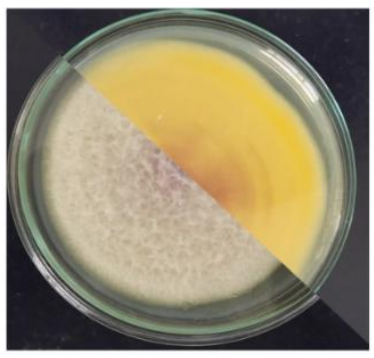

(c)

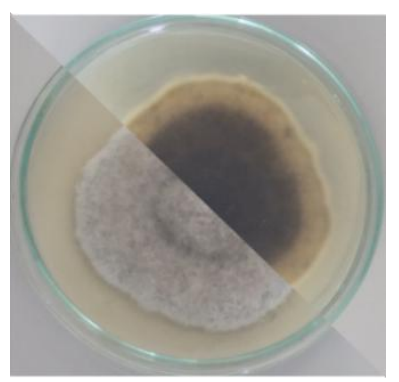

(d)

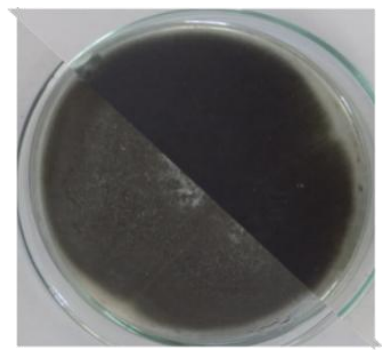

(e)

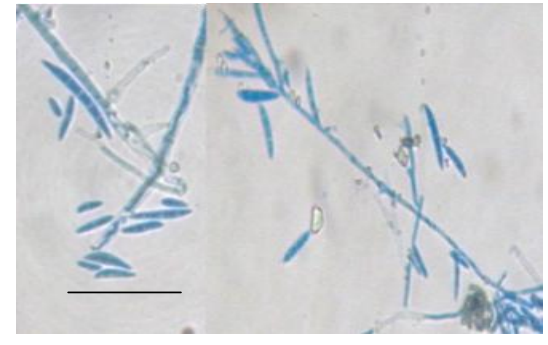

(f)

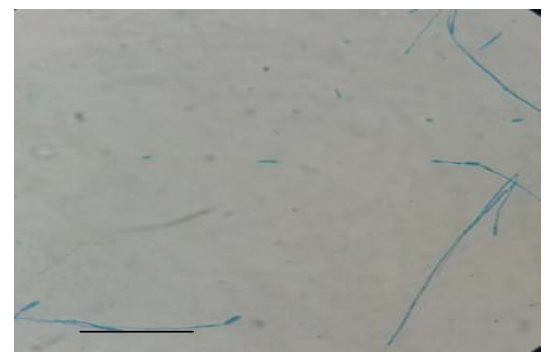

(g)

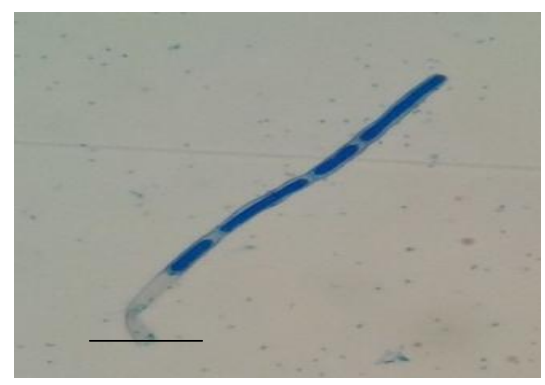

(h)

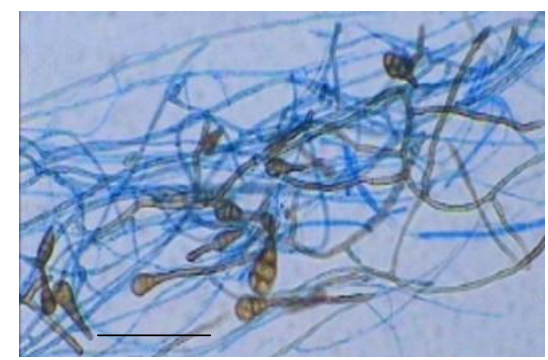


Fig.2 Fig.2 Pathogenicity test of isolated fungi on cotton plant (a)Control, (b)Fusarium chlamydosporum, (c) Fusarium moniliforme,(d)Corynespora cassicola and (e)Alternaria sp.

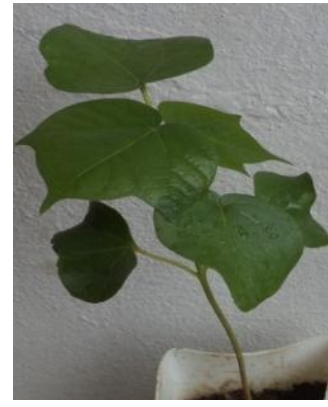

(a)

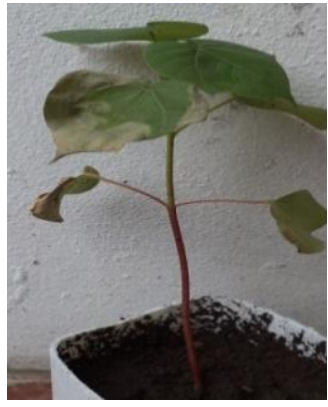

(b)

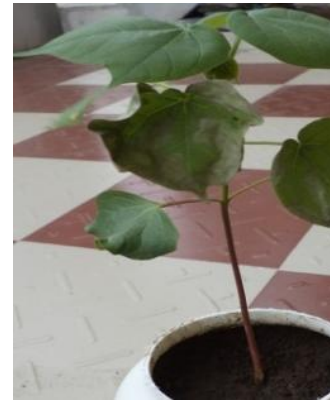

(c)

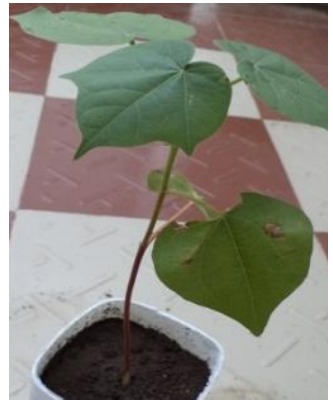

(d)

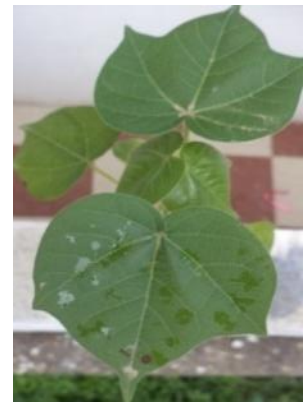

(e)

Fig.3 Pathogenicity test of isolated fungi on cotton seeds (a) Control (b) Fusarium chlamydosporum (c) Fusarium moniliforme (d) Corynespora cassicola (e) Alternaria sp.

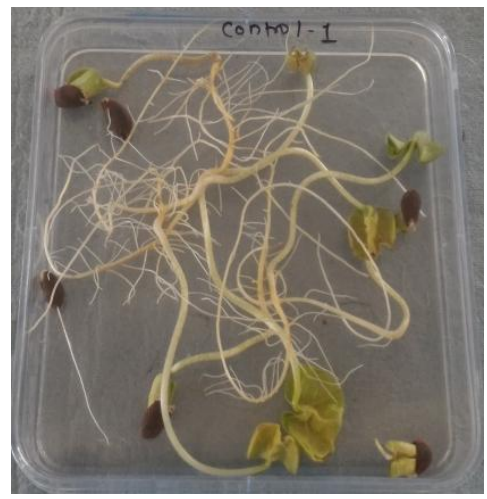

(a)

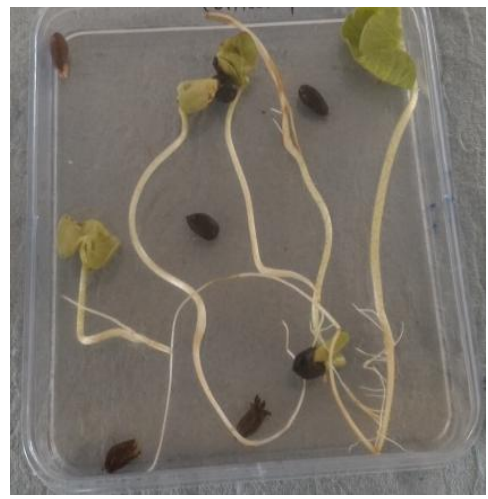

(b)

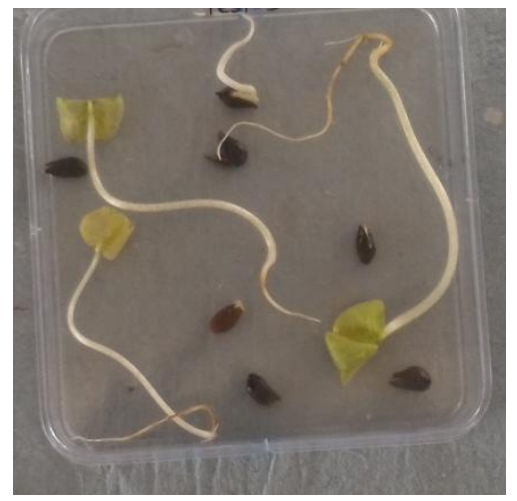

(c)

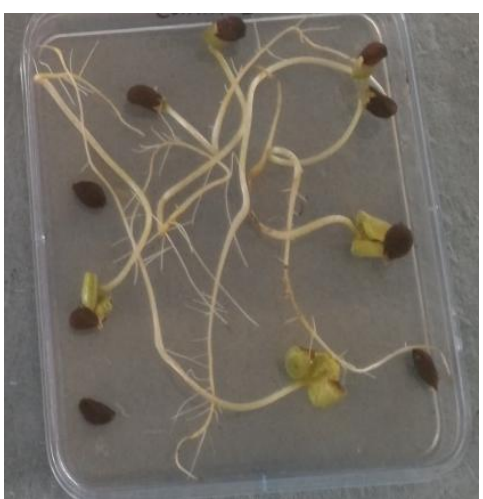

(d)

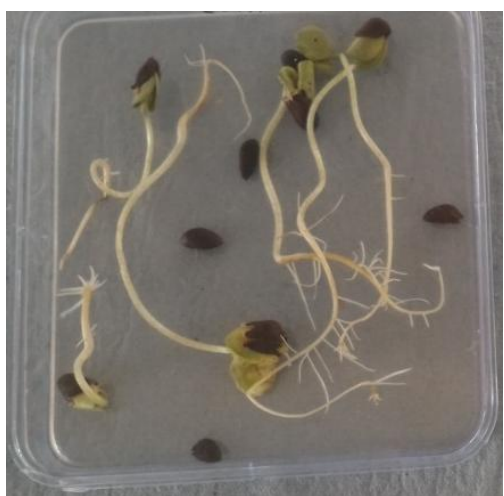

(e) 
Fig.4 Effect of fungal isolates on cotton seed germination ( $\square$ seed treatment, $\square$ soil treatment).

Bars with the same letter are not significantly different. ${ }^{a} \mathrm{P}>0.05$ Vs. control after treatment;

${ }^{\mathrm{b}} \mathrm{P}<0.05$ Vs. control after treatment

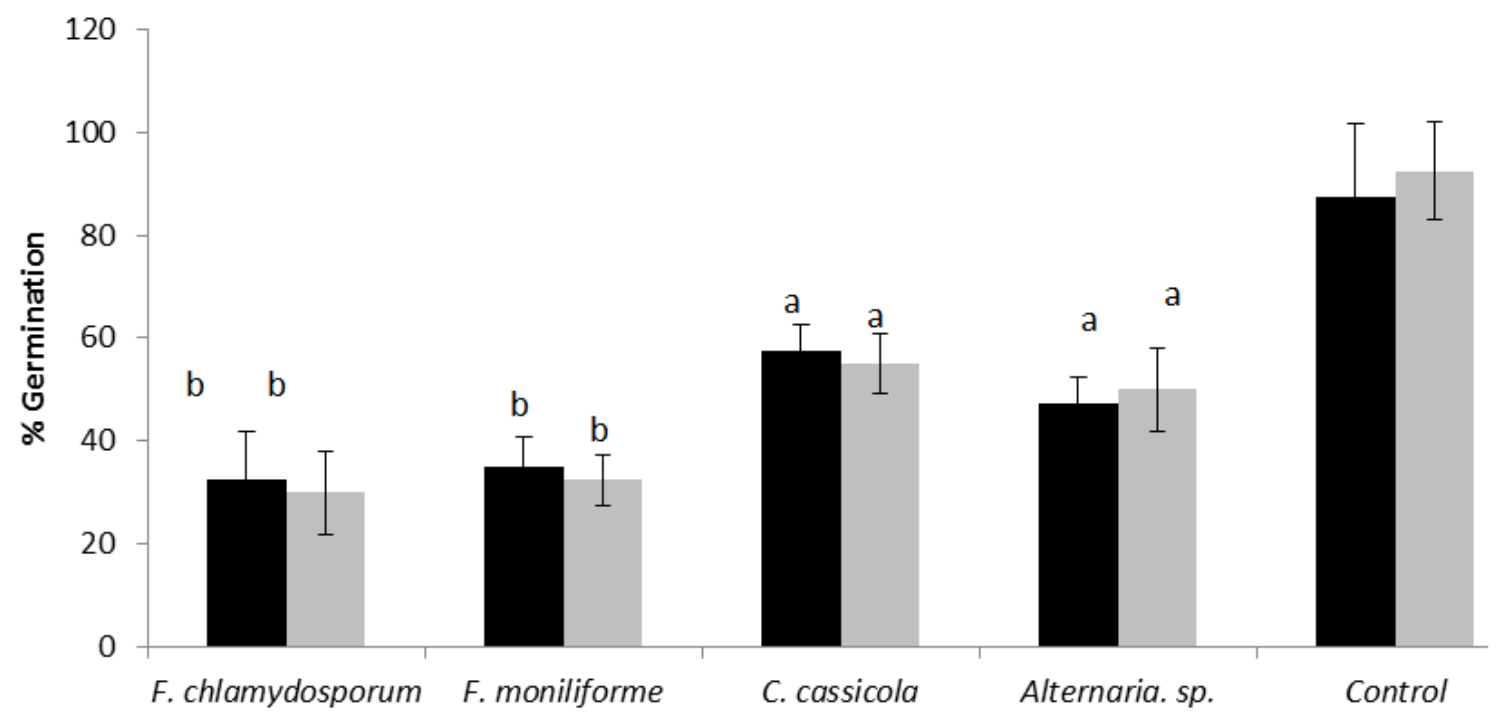

The vigor index of cotton plant in soil treatment method was consistently lower than seed treatment method. The Fusarium chlamydosporum and Fusarium moniliforme have contributed in maximum reduction in plant vigor. Similarly Corynespora cassicola and Alternaria sp. also showed considerable reduction in cotton plant vigor compared to control (Table 5).

The extensive field surveys of various regions of North Maharashtra indicated the prevalence of various fungal infections on Bt cotton plant. During survey cotton plants with wilting, leaf spot of brown, black \& pale yellow color, reduced height, less vigorous growth of plantand boll infection were considered symptoms. Total 4 fungal strains - Fusarium fusarioides (syn. =chlamydosporum) (NFCCI 2948); Fusarium moniliforme (NFCCI 2949); Corynespora cassicola (NFCCI 2952); Alternaria sp. (NFCCI 2955) were isolated from different plant parts indicating that different fungi targets different part of plant for their successful colonization in plant. Among these isolates, Fusarium chlamydosporum and Fusarium moniliforme are known to cause seedling disease complex causing pre and post-emergence damping off and seedling root rot diseases (Abd-Elsalam et al., 2006, Costa et al., 2005); while Alternaria sp. and Corynespora cassicola were reported to cause foliar diseases (Bashan et al., 1991, Galbieri et al., 2014).

The wilt disease incidence on cotton plants sowed in May was higher than cotton plants sowed in June. This may be due to the favorable climate for fungi causing wilt disease (like Fusarium species). In irrigated fields, due to adequate/excess supply of water and higher temperature (above $40^{\circ} \mathrm{C}$ ) elevate the humidity which promotes the growth of fungi causing wilt disease. On the other hand foliar disease incidences are less (18\%) on cotton plants sowed in May than cotton plants sowed in June. This might be due to foliar disease causing fungi cannot 
tolerate the heat of May and hence could not develop at younger stage.

The pathogenicity test on cotton plant stated that all the isolates are potential phytopathogens which can lead to severe crop damage. The pathogenicity of 4 different fungi attributed to 4 different genera was tested against cotton plant. All the four fungal species were positive and potentially infect to the cotton plant by inducing various symptoms like root browning, wilting and leaf spots. Fusarium isolates showed direct influence on reduction of plant height, vigor, and root length. Among the other pathogens Corynespora cassicola was the aggressive one and causes leaf spot disease. Alternaria sp. also showed effective disease severity index.

Majority of fungal pathogen attacks during the seed germination (the fungal pathogen may be seed borne/soil borne). Among the isolated fungal pathogens, Fusarium chlamydosporum and Fusarium moniliforme showed a greater impact in reduction of cotton seed germination. Even the germinated seeds (treated with F.chlamydosporum and Fusarium moniliforme) after emergence up to the entire plantlet showed reduced vigor, vitality, boll formation and overall reduced plant health.

Although Corynespora cassicola and Alternaria sp. did not show much impact in reduction of seed germination, but the foliar disease symptoms were observed at mature stage showed a moderate effect in reduction of cotton seed germination. From these results it can be concluded that the isolated fungal strains are potential phytopathogens and have the capacity to induce infection to plantlet as well as during germination of cotton seed.

\section{References}

Abd-Elsalam, K., Asran-Amal, A., Omar, M.R. and Aly, A. 2006. Frequency and diversity of Fusarium spp. Colonizing roots of Egyptian cottons. Arch. Phytopathol. Plant Protect, 39: 165-177.

Agrios, G.N. 2005 - Plant Pathology. $5^{\text {th }}$ ed. Elsevier Academic Press, San Diego, California pp.3-15

Alexopoulos, C.J., Mims, C.W. and Blackwell, M. 1996. Introductory Mycology. Fourth Edition. John Wiley \& Sons Inc., New York.pp. 245,436.

Bashan, Y., Levanony, H. and Or, R. 1991. Association between Alternaria macrospora and Alternaria alternata causal agents of cotton leaf blight. Can. J. Bot., 69: 2603-2607.

Bell, A.A. 1999. Diseases of Cotton. In: Cotton: Origin, History, Technology and Production (Eds.) Smith, W.C., Cothren, J.T. John Wiley and Sons, Inc, New York, USA. pp 553-559.

Costa, M.L.N., Dhingra, O.D. and Silva, J.L. 2005. Influence of internal seed borne Fusarium semitectum on cotton seedlings. Fitopatologia Brasileira, 30: 183-186.

Dugan, F.M. 2006. The Identification of Fungi: An Illustrated Introduction With Keys Glossary and Guide to Literature. The American Phytopathological Society. Press, St. Paul. Minnesota.

Farrell, T. and Johnson, A. 2005. Cotton pest management guide2005-06. NSW Department of Primary Industries; Cotton Catchment Communities CRC, Australia.

Galbieri, R., Araujo, D.C.E.B., Kobayasti, L., Girotto, L., Matos, J.N., Marangoni, M.S., Almeida, W.P. and Mehta, Y.R. 2014. Corynespora 
Leaf Blight of Cotton in Brazil and Its Management. Am. J. Plant Sci., 5: 3805-3811.

Gopalakrishnan, N., Manickam, S. and Prakash, A.H. 2007. Problems and prospects of cotton in different zones of India. In: Gopalakrishnan, N., Manickam, S. and Sabesh, M. (Ed.), Model training course on: Cultivation of long staple cotton (ELS). Central Institute for Cotton Research, Regional Station, Coimbatore, Tamil Nadu.

Islam, N.F. and Borthakur, S.K. 2012. Screening of mycota associated with Aijung rice seed and their effects on seed germination and seedling vigour. Plant Pathol. Quar. J. Fungal Biolog., 2: 75-85.

Khadi, B.M., Santhy, V. and Yadav, M.S. 2009. Cotton: An Introduction. In: Zehr U (ed) Biotechnology in Agriculture and Forestry. Vol.65 Cotton- Biotechnological Advances. Springer-Verlag Berlin Heidelberg, pp. 1-2.

Lee, K.J., Kamala- Kannan, S., Sub, H.S., Seong, C.K. and Lee, G.W. 2008. Biological control of phytophthora blight in red pepper (Capsicum annuum L.) using Bacillus subtilis. World J. Microbiol. Biotechnol., 24: 1139-1145.

Patil, S.J. and Waykole, M. 2013.Status of Cotton Global to Khandesh. Global Res. Anal., 2: 136-139.

Shin, S., Kyeong-Hoon, K., Chon-Sik, K., Kwang-Min, C., Chul, S.P., Ron, O. and Jong-Chul, P. 2014. A simple method for the assessment of
Fusarium head blight resistance in Korean wheat seedlings inoculated with Fusarium graminearum. Plant Pathol. J., 30(1): 25-32.

Shtienberg, D. 1996. Variables associated with intensity of Alternaria leaf spot in pima cotton. Phytopathol., 86: 123-128.

Williams-Woodward, J. 2001. Simplified Fungi Identification Key. Special Bulletin 37, The University of Georgia. http://plantpath.caes.uga.edu/extensi on/documents/fungikey.pdf

WWF-India report. 2012. Cotton market and sustainability in India. WWFIndia- Yes Bank. pp.7.

Zhao, B., Yan. J., Zhang, S., Liu, X. and Gao Z. 2014. Phylogeny and pathogenicity of Fusarium spp. isolated from greenhouse melon soil in Liaoning Province. Saudi J. Biol. Sci., 21(4): 374-379.

Zheng, Y., Xue, Q., Xu, L., Xu, Q., Lu, S., $\mathrm{Gu}$, C. and Guo, J. 2011. A screening strategy of fungal biocontrol agents towards Verticillium wilt of cotton. Biol. Control, 56: 209-216.

\section{How to cite this article:}

Leena P. Shirsath and Ulhas K. Patil. 2016. Prevalence of Fungal Phytopathogens on Transgenic Bt Cotton Plant: Isolation and Characterization. Int.J.Curr.Microbiol.App.Sci. 5(9): 682-693. doi: http://dx.doi.org/10.20546/ijcmas.2016.509.079 